\title{
WORK-RELATED ATTITUDES: A COMPARISON OF ESTONIA AND FINLAND
}

\author{
Ruth Alas ${ }^{1}$, Vincent Edwards ${ }^{2}$ \\ ${ }^{1}$ Professor of Management Estonian Business School, Lauteri 3, 10114 Tallinn, Estonia, \\ Phone: +372 6651346; Fax: +372 6313959; E-mail: ruth.alas@ebs.ee \\ ${ }^{2}$ Professor of East European Management and Culture, Buckinghamshire Chilterns University College, \\ United Kingdom, Phone: +44 (0)1494 603069; Fax:+44 (0)1494 874230; E-mail: vince.edwards@bcuc.ac.uk
}

Received 1908 2005; accepted 08112005

\begin{abstract}
Although Estonia and Finland are culturally related, according to an empirical study in the electronics industry in the two countries they display significant differences in job-related attitudes. This paper investigates employees' attitudes toward society, trade unions, work, employer organisations and pay determinants in the two countries from an institutionalist and cultural perspective. While Finland has experienced almost a century of capitalism and democracy, work-related attitudes in Estonia have been particularly affected by the 50 years of Soviet rule. It is argued that the differences in work-related attitudes are influenced inter alia by differences in levels of institutional development.
\end{abstract}

Keywords: Estonia, Finland, institutionalism, attitudes, trade unions, job satisfaction.

\section{Introduction}

The enlargement of the European Union (EU) on 1 May 2004 has resulted in institutional changes not only in acceding countries, but also in existing members. A widely discussed topic is the free movement of workers. According to European Community Treaty EU citizens have the right to reside in a host country in order to seek employment there, to bring the family to join them during work, and also to remain in that country after employment. Numerous forecasts have been made of possible labour movement from candidate countries after accession and in some existing EU countries there is considerable anxiety regarding the possible negative effects on their own labour markets ('The Free Movement of Workers in the Context of Enlargement', 2001).

According to an international survey there are significant differences in the attitudes toward society, organisations and work, held by people in countries with different levels of institutional development (Alas 2003). At the same time a person's attitudes influence the person to act in a certain way instead of another
(Cooper and Croyle, 1984), specially in an environment, where multiple interacting changes have led to a highly complex, confusing and unpredictable state of being - chaos. In this situation, instead of planned change, with its focus on the effort involved in change and the overall change strategy, there is an emphasis on the process of change and on attitudes to change (Bergquist, 1993). Research results in Estonian organisations indicate that aspects of organisational culture influencing organisational change have a differentiated impact on the formation of attitudes toward change (Alas and Vadi, 2004) and on the formation of attitudes toward learning (Alas and Vadi, 2003), depending on the particular level of institutional development. Attitudes toward both change and learning are crucial in continuously changing contemporary organisations, especially in a country undergoing considerable change.

Estonia is new EU member and Estonian citizens can now choose to seek employment in another member country. As many Estonians seek short-term jobs in Finland, where salaries are much higher than in Estonia (Narusk, 2004), this free movement of workers 
could be seen as a problem from the Finnish side. This paper analyses the work-related attitudes of Estonian and Finnish employees. The main research question is: are there differences in work-related attitudes between Finnish and Estonian employees? In order to gain a better understanding, reasons for such differences are investigated. Sahlins (1985) argues that one cannot really understand certain social phenomena without understanding both the historical events and the cultural meanings attributed to these events by the actors involved. This paper therefore explores the extent to which knowledge of society influences people's attitudes. This study investigates how different stages of institutionalisation influence employee attitudes toward society, trade unions, the organisation and work. The paper begins with a theoretical overview of the connections between attitudes and institutionalism. This is followed by a comparison of historical developments in Estonia and Finland from a socio-economic perspective in order to identify the reasoning behind the differences in attitudes. In this respect, institutionalism is used as a comparative instrument. Finally data collected from empirical studies in both countries are analysed and the results discussed.

\section{Institutionalism and attitudes}

Institutionalists stress the importance of the institutional environment in order to understand behaviour. Institutions find expression in society through social constructions: macro level, formal institutions in market economies include private property and the free market; micro level, formal institutions include organisations. Individual organisations are under the technical and normative influence of institutionalised environments. Formal institutions, moreover, exist side-by-side with informal institutions such as the family and friendship groups.

Institutions can be seen from both a structural and social perspective. In the structural view institutions exist as institutionalised forms of 'external social constraints'. From the social perspective institutions can be understood as operating as behavioural definitions, which may take the form of either 'cultural accounts' or 'cultural rules'. This means that institutions provide an account of how the social world works and embody normative principles and social values (Meyer et al., 1994:24). Values influence attitudes and the strength of attitudes (Boninger et al., 1995). It has also been postulated that attitudes motivate behaviour and exert a selective influence at various stages of information processing (Eagly and
Chaiken, 1993:1). Employee attitudes have even been considered an indicator of the future success of an organisation (Hurst, 1995). One widely researched attitude is job satisfaction, which has been defined as a pleasurable emotional state resulting from the appraisal of one's job (Locke, 1976), and is considered as a combination of attitudes about various aspects or facets of the job, which form the overall job satisfaction construct (Spector, 1997). Despite the amount of interest in this area findings are still contradictory (Meyer and Allen, 1997:43-45) and vary across different social, political and economic environments in different countries (Judge et al., 2001).

Researchers have also found that general job satisfaction ("How satisfied are you with your job in general?") and the sum of the facets of job satisfaction are not equal and there is no commonly accepted list of facets, forming the construct (Brief, 1998). Furthermore, the changing nature of work can affect the facets contributing to general job satisfaction, making it worth while investigating job satisfaction again and simultaneously in different countries and to examine the influence of the broader environment upon attitudes. Several studies have shown job satisfaction as a contributor to and predictor of organisational commitment (Johnson and JonesJohnson, 1992; McNeese-Smith and Nazarey, 2001) which O'Reilly and Chatman, (1986) define as a psychological attachment to the organisation.

The structural perspective on institutionalism draws attention to the institutional flexibility of the labour market. Trade unions are considered an important labour market institution (Hinnosaar, 2003). Trade unions are nationally embedded social institutions, influenced by historical experience and current institutional configurations (Wood and Brewster, 2002: 255). Trade unions like other organisations are under the technical and normative influence of institutionalised environments and each country's union movement has a distinctive structure and mode of operating (Freeman, 1994). Trade unions are, moreover, institutions in which representatives negotiate on behalf of the membership (Fairbrother, 2000). They represent employees' interests to management by negotiating wages for their members and influencing fringe benefits, productivity, work allocation, job security and employee participation practices. But trade unions may also influence the terms of employment for non-union members through a spillover effect which may be expressed through an extension of agreements and employer responses to unionised environments (Bean and Holden, 1994). In democratic societies trade unions are voluntary 
organisations that require a level of member participation in order to function. The relationship between the members and the union is based on prior experience and could be seen in the context of the longer term as being based on trust rather than on short-term economic exchange (Bamberger et al., 1999).

From this institutional perspective, socio-economic transition at both macro and micro levels can be understood as institutional change from both the structural and social perspective, embracing both structures and social values. As institutional elements lose credibility and are redefined, the processes of deinstitutionalisation and reinstitutionalisation take place. During deinstitutionalisation the contingent nature of cultural accounts and rules are revealed, interrogated, contested, opposed, effectively challenged and ultimately overturned. The process may be gradual or sudden and may affect formal institutions and institutional practices at different rates. Deinstitutionalisation takes away the certainty associated with institutionalised rules, attacks the meaningfulness of the social word and thereby reduces the level of social support and motivation. Reinstitutionalisation involves the construction of new formal institutions and the realisation of new social practices. During this process patterns and activities are redefined on the basis of values, which differ from values previously taken for granted. New social practices evolve slowly because the values and their underlying logic take time to become reproduced unquestioningly in routine conduct (Clark and Soulsby, 1999: 40).

Social transition may thus be interpreted as the period between the effective demise of one institutional system and the point at which another institutional system has become established and accepted on new cognitive and normative grounds. Such circumstances create acute social and psychological problems for social actors and this period has been called social transience (Clark and Soulsby, 1999:40).

Work-related values can therefore be regarded as the outcome of the intricate interaction of a number of factors which include the national cultural and institutional context, the specific industry context, the organisational environment and, finally, the characteristics of individuals themselves. Hickson and Pugh (2001) have commented on the difficulty of defining what culture is. For example, definitions of culture focused on aspects such as 'values' are merely replacing one opaque term with another. Nevertheless, values may be considered one constituent element of culture and Schneider and Barsoux (1997) distinguish three levels of culture: artifacts and behaviour; beliefs and values; and basic assumptions about existence and the world.

However, as Tayeb (1991) has argued, other factors apart from cultural upbringing influence employees' work-related values. Notwithstanding the above comments and the complexity of the issues involved, in this study we focus particularly on the cultural and institutional context and have sought to limit the impact of other factors by selecting similar industries and organisations in Estonia and Finland. Differences in individual characteristics were, it was considered, limited by the use of relatively large samples in both countries.

\section{A historical comparison of Estonia and Finland}

Estonians and Finns have reacted to the same or similar political pressures, which have been intrinsic to their geopolitical location close to Russia and between the East and the West (Nurmi and Üksvärav, 1994: 19). Both countries share the same heritage as Finno-Ugric nations. They have very similar languages and cultures and two-thirds of their genetic background is shared (Nurmi and Üksvärav, 1994: 26). The dominant religion in both countries is Lutheranism.

According to the comparison in Table 1 their histories were quite similar until 1940. Both nations had been under foreign rule until 1917. During this period both countries were even parts of the same state on two occasions: from 1629-1710 under Swedish rule and from 1809-1917 under Russian rule (Nurmi and Üksvärav, 1994: 10). Both countries declared their independence in the aftermath of World War I and progressed through a period of swift development and industrialisation during the decades of independence between the World Wars. During independence Western values relating to attitudes to work, individualism and free enterprise were adopted and institutions common to a market economy established. Estonia and Finland had relatively close cultural ties during this period (Raun, 1987:16) and were more or less on a similar economic level in 1940 (Laar 2001: $31)$.

The fate of Estonian independence was sealed on 23 August 1939 with the secret 'additional protocol' of the Molotov-Ribbentrop Pact between Nazi Germany and the Soviet Union, which assigned Estonia to the Soviet sphere of influence (Misiunas and Taagepera, 1983: 15). 
Table 1. A comparison of Estonian and Finnish history from an institutional perspective.

\begin{tabular}{|l|l|l|l|l|}
\hline Period & \multicolumn{2}{|c|}{ Event } & \multicolumn{2}{c|}{ Institutionalisation } \\
\multicolumn{1}{|c|}{ Finland } & Finland \\
\hline $\begin{array}{l}1900- \\
1917\end{array}$ & Estonia & Institutions changed over time \\
\hline $\begin{array}{l}1917- \\
1940\end{array}$ & Creation of independent states & $\begin{array}{l}\text { Creation of new institutions, followed by a period of stable } \\
\text { institutions }\end{array}$ \\
\hline $\begin{array}{l}1940- \\
1950\end{array}$ & Soviet occupation & $\begin{array}{l}\text { War with Soviet Union, } \\
\text { Independence continues }\end{array}$ & $\begin{array}{l}\text { Deinstitutionalisation and } \\
\text { reinstitutionalisation }\end{array}$ & $\begin{array}{l}\text { Period of stable } \\
\text { institutions }\end{array}$ \\
\hline $\begin{array}{l}1950- \\
1987\end{array}$ & Under Soviet rule & Independence & Period of stable institutions & Stable institutions \\
\hline $\begin{array}{l}1987- \\
1991\end{array}$ & $\begin{array}{l}\text { Economic Self-Mangement } \\
\text { proposal (IME), movement } \\
\text { toward independence }\end{array}$ & Independence & $\begin{array}{l}\text { Creation of additional } \\
\text { institutions }\end{array}$ & Stable institutions \\
\hline 1991 & $\begin{array}{l}\text { Re-establishment of } \\
\text { independent state }\end{array}$ & Independence & Deinstitutionalisation & Stable institutions \\
\hline $\begin{array}{l}1991- \\
1995\end{array}$ & $\begin{array}{l}\text { Transition from planned to } \\
\text { market economy }\end{array}$ & Independence & Social transience & Stable institutions \\
\hline $1995-$ & More stable economic & Accession to European & Reinstitutionalisation, \\
& Situation, market economy & Union & $\begin{array}{l}\text { Creation of some } \\
\text { additional institutions }\end{array}$ \\
\hline
\end{tabular}

To provide some socio-economic background, which is rooted in both past and present circumstances of societal and organisational transition, a brief outline of the main stages of Estonian history, starting from the first period of independence will be given.

After Soviet occupation in 1940, the subsequent period of fifty years under different economic and political systems led to vastly different economic structures and behavioural patterns and opened up a huge divergence between the development of Finland and Estonia (Laar, 2001 31). Finland maintained its independence and could function in a stable institutional environment. Following the occupation of Estonia in 1940 all civil institutions characteristic of the Western world were liquidated or restructured according to Soviet principles, with the aim of using them in the process of building communism (Taagepera, 1993: 65).

The Soviet Union started rapid Sovietisation in Estonia, involving the pursuit of two goals: state socialism and Russification (Taagepera, 1993: 106). Between 1940 and 1955 Estonia lost 25-30 percent of its original population (Laar, 2001: 28). This included mass deportations throughout the 1940s (Taagepera, 1993). A large Soviet military garrison and the continual influx of Russian speaking colonists replaced the lost population. Whereas in 1945 Estonians had constituted 94 percent of the population, by 1989 they amounted to only 62 percent.

A state socialist society was built upon a centralised, hierarchical state coordinated through bureaucratically administered structures. Political, economic and other forms of institutional power were drawn from the same source and operated in a unidirectional manner, providing for effective control and a concentration of information. Since during the Soviet period the state was responsible for guaranteeing work for everyone, enterprises were overstaffed and passive. Work places were over-secured (Liuhto, 1999: 16).

Although the Soviet regime was successful in eliminating private enterprise, introducing stateoriented socio-economic institutions and getting the population accustomed to them (Taagepera, 1993: 108), its attempt at Russification was not successful. The majority of Estonians did not accept the Soviet identity as their own and maintained their national and cultural identity in traditions from the first Estonian republic, which were kept alive in Estonian family life (Laar, 2001: 48). Estonians developed two levels of communication: they learned to speak and use the official communist language and dogma in public as a form of lip service; and a second and genuinely national communication was used in families and with close friends. Children learned this communicative finesse before school age (Nurmi and Üksvärav, 1994). Estonians could thus declare their national values again publicly as soon as it became possible in the second half of the1980s.

A comparison of Estonia and Finland after the Soviet occupation demonstrates that the Soviet regime brought a significant decline in the standard of living in Estonia (Misiunas and Taagepera, 1983: 39). In 1988 household income per capita in Finland was 4.6 times higher than in Estonia. In 1987 there were nearly 400 cars per 1000 inhabitants in Finland. In Estonia the corresponding figure was 150 . The number of private cars in Estonia in 1987 was on the same level as South Africa (107) and Argentina (125). There were also differences in quality of housing (45 telephones per 100 inhabitants in Finland compared to 12 in Estonia). These data indicate that at the end of the 
1980s the level of economic development and standard of living in Finland by far exceeded Estonia's. In Soviet Estonia the trade unions, rather than articulating the interests of workers to employers and the state (Muller-Jentsch, 1985) acted as a tool of communist propaganda. Union membership was compulsory.

When Estonia regained its independence in 1991 and began to rebuild the institutions destroyed in 1940, during this period of social transience the trade union system was also dismantled and union membership declined to 11-12 percent of the workforce (Vare 2000). In comparison, between 1970-89 among OECD countries, Finland showed the most positive changes in trade union membership (Bean and Holden 1994). Moreover, in the period preceding Estonia's EU accession there continued to be major differences in economic development between Estonia and Finland (see Table 2).

In summary it is proposed that (1) the 50 -year period of Soviet occupation strongly influenced people's attitudes, including their attitudes to work. Moreover (2), changes in Estonian society during economic transition, which resulted in the collapse of structures, systems, rules and principles that had made human behaviour and social life understandable for over 50 years and now left a vacuum of meaning, had an impact upon people's attitudes. These experiences were very different from that of Finland.

To explore the differences in people's attitudes empirical data from the Denki Ringo research project was used (see below).

\section{Methodology and sample}

An attitude survey was conducted in two plants of the electronics industry in both Estonia and Finland: one produces telecommunications equipment and the other electrical goods for household use. A standardised questionnaire comprising 39 items was developed by the Denki Ringo research group and translated from English into Estonian, Finnish and Russian. The questionnaire was administered in both countries. The questions in the survey addressed expectations of society, trade unions, feelings toward organisations, pay determinants and some other issues. Job satisfaction was measured in two different ways. In the first part of the questionnaire 15 facets of job satisfaction were evaluated on a five-point scale and later, among questions about age and marital status, there was a single question about general satisfaction with working life.

There were 545 respondents from Estonia and 339 respondents from Finland in the sample. The average age of Finnish respondents was higher than that of Estonian respondents: 50.6 percent of Estonians were under 35, compared to 41.2 percent in the Finnish sample. The educational level was higher in Estonia: 63 percent of respondents had high school or university level education, compared to 53.2 percent in Finland. In Finland 55.2 percent of respondents were male, in Estonia only 19.3 percent. In Finland work experience was longer: only 29.7 percent of employees had worked less than 5 years, compared to 64.5 percent in Estonia. As the younger, better educated Estonians are more likely to go abroad to work (Kallaste and Philips 2003), these data were considered appropriate for the purposes of this research.

Data from the two countries were compared by means of the T-Test. The factors influencing job satisfaction and organisational commitment were identified by using Linear Regression analysis.

\section{Results}

\section{Attitudes toward society}

Table 3 shows what kind of society people think their country should be according to Estonian respondents in the first two columns and according to Finnish respondents in the last two columns. Although there are statistically significant differences between the two countries in five of the eight items, the rankings of values do not differ much. The largest difference between the two countries is in the evaluation of

Table 2. GDP and unemployment in Estonia and Finland

\begin{tabular}{|l|l|l|}
\hline Economic indicator & Finland & Estonia \\
\hline GDP per capita 2003 USD & 31118 & 5985 \\
\hline GDP/PPP per capita 2003 USD & 26972 & 12190 \\
\hline GDP annual growth rate 2001 & 1.1 & 6.5 \\
2002 & 2.3 & 6.0 \\
2003 & 1.9 & 4.7 \\
\hline Unemployment rate 2001 & 9,2 & 12,6 \\
\hline
\end{tabular}

Source: Statistics Finland, National Accounts; http://www.stat.fi/tk/tp/maailmanumeroina/index_en.html 
Table 3. Preferred society according to Estonian and Finnish respondents

\begin{tabular}{|c|c|c|c|c|}
\hline & $\begin{array}{l}\text { Estonia } \\
\mathrm{N}=535\end{array}$ & $\begin{array}{l}\text { Mean } \\
\text { SD }\end{array}$ & $\begin{array}{l}\text { Finland } \\
\mathrm{N}=324\end{array}$ & Mean SD \\
\hline 1. & $\begin{array}{l}\text { People are provided with a good material standard of } \\
\text { living }\end{array}$ & $\begin{array}{l}1.33 \\
.59\end{array}$ & $\begin{array}{l}\text { Social order is kept with few criminal } \\
\text { offences }\end{array}$ & $\begin{array}{l}1.21 \\
.36\end{array}$ \\
\hline 2. & People can live with peace of mind & $\begin{array}{l}1.33 \\
.69\end{array}$ & People can live with peace of mind & $\begin{array}{l}1.24 \\
.32\end{array}$ \\
\hline 3. & Social order is kept with few criminal offences & $\begin{array}{l}1.33 \\
.61\end{array}$ & $\begin{array}{l}\text { People can acquire all the results of their own } \\
\text { work }\end{array}$ & $\begin{array}{l}1.32 \\
.53\end{array}$ \\
\hline 4. & $\begin{array}{l}\text { Individuals can develop their lives with great } \\
\text { opportunities }\end{array}$ & $\begin{array}{l}1.35 \\
.67\end{array}$ & $\begin{array}{l}\text { Individuals can develop their lives with great } \\
\text { opportunities }\end{array}$ & $\begin{array}{l}1.62 \\
.66\end{array}$ \\
\hline 5. & People can acquire all the results of their own work & $\begin{array}{l}1.45 \\
.71\end{array}$ & $\begin{array}{l}\text { Everyone cooperates with each other with } \\
\text { solidarity }\end{array}$ & $\begin{array}{l}1.70 \\
.62\end{array}$ \\
\hline 6. & $\begin{array}{l}\text { People live life by observing well-established values } \\
\text { and ethics }\end{array}$ & $\begin{array}{l}1.64 \\
.69\end{array}$ & $\begin{array}{l}\text { People live life by observing well-established } \\
\text { values and ethics }\end{array}$ & $\begin{array}{l}1.78 \\
.69\end{array}$ \\
\hline 7. & Everyone cooperates with each other with solidarity & $\begin{array}{l}1.74 \\
.73\end{array}$ & $\begin{array}{l}\text { People are provided with a good material } \\
\text { standard of living }\end{array}$ & $\begin{array}{l}1.80 \\
.80\end{array}$ \\
\hline 8. & Social equality among people is highly developed & $\begin{array}{l}1.99 \\
.86\end{array}$ & $\begin{array}{l}\text { Social equality among people is highly } \\
\text { developed }\end{array}$ & $\begin{array}{l}1.93 \\
.65 \\
\end{array}$ \\
\hline
\end{tabular}

Notes: A 4-point scale was used where '1' signifies 'very important' and '4' 'not important'.

Bold notes statistically significant differences between Estonia and Finland, $\mathrm{p}<.05$.

material standards of living. In the case of Estonia it was the most valued factor, whereas in Finland it was almost the least valued $(\mathrm{F}(1 ; 523)=39.658, \mathrm{p}=.000)$.

\section{Attitudes toward Trade Unions}

The results in Table 4 indicate that in Estonia trade union (TU) membership was only 5 percent as opposed to 80 percent in Finland $(\mathrm{F}(1 ; 868)=5.385$, $\mathrm{p}=.021)$. The number of people who had given up TU membership was 52.5 percent in Estonia compared to 2 percent in Finland. At the same time 59 percent of TU members in Finland never participated in local union activities.

Respondents from Finland found that decisions made by local unions better reflected their opinions than respondents from Estonia $(F(1 ; 852)=208.343, p=.000)$. Although respondents from both countries found that the most important spheres of activity for a TU were job security, employment protection and wage increases, there were also some differences. Respondents from Finland put more emphasis than Estonians on increasing influence upon management policies $(\mathrm{F}(1 ; 835)=15.815, \mathrm{p}=.000)$, upon promoting employees $(F(1 ; 834)=21.691, p=.000)$, upon the amount of work and the methods of work $(\mathrm{F}(1 ; 850)=9.869, \mathrm{p}=.002)$ and the reduction of working hours $(\mathrm{F}(1 ; 849)=19.860, \mathrm{p}=.000)$. In contrast, respondents from Estonia were more interested in regulating holiday policy $(\mathrm{F}(1 ; 848)=43.814, \mathrm{p}=.000)$ than their Finnish counterparts.

\section{Attitudes to pay determinants}

Table 5 shows the ranking of features considered important in the setting of pay schedules in both countries. Although all indicators except required skills were evaluated differently statistically, the greatest differences in the ranking concern company performance and working conditions. For Estonian respondents unpleasant working conditions were the second most important factor; this was not the case in Finland. Finnish employees, moreover, wanted their pay linked to company performance, which was not the case in Estonia. However, there are also similarities. Both countries ranked skills and results highly. At the same time socio-demographic characteristics such as gender, age and family size were not considered particularly important in either country.

Table 4. Trade Union membership and participation in the work of Trade Unions by workers from Estonia and Finland

\begin{tabular}{|l|r|r|r|r|r|}
\hline TU members & \% in Estonia & \% in Finland & TU participation among members & \% in Estonia & \% in Finland \\
\hline Never & 39.2 & 16.8 & Whenever possible & 1.9 & 2.9 \\
\hline Yes, in the past & 52.5 & 2.1 & Often & .6 & 1.5 \\
\hline Yes, now & 5.1 & 80.3 & Sometimes & 5.3 & 7.1 \\
\hline Total & 96.7 & 99.1 & Seldom & 3.4 & 29.5 \\
\hline Missing & 3.3 & .9 & Never & 88.9 & 59.0 \\
\hline Total & 100.0 & 100.0 & Total & 100.0 & 100.0 \\
\hline
\end{tabular}


Table 5. Determinants of pay according to Estonian and Finnish respondents

\begin{tabular}{|c|c|c|c|c|}
\hline & $\begin{array}{l}\text { Estonia } \\
\mathrm{N}=535\end{array}$ & Mean SD & $\begin{array}{l}\text { Finland } \\
\mathrm{N}=337\end{array}$ & Mean SD \\
\hline 1. & Skills required for the job & $\begin{array}{l}1.24 \\
.49\end{array}$ & Company performance & $\begin{array}{l}1.25 \\
.53\end{array}$ \\
\hline 2. & Unpleasant working conditions & $\begin{array}{l}1.29 \\
.52\end{array}$ & Skills required for the job & $\begin{array}{l}1.28 \\
.51 \\
\end{array}$ \\
\hline 3. & Achievement of tasks & $\begin{array}{l}1.29 \\
.56\end{array}$ & Achievement of tasks & $\begin{array}{l}1.37 \\
.56 \\
\end{array}$ \\
\hline 4. & Responsibility on the job & $\begin{array}{l}1.34 \\
.60 \\
\end{array}$ & Physical load & 1.57 \\
\hline 5. & Mental load & $\begin{array}{l}1.62 \\
.71\end{array}$ & Responsibility on the job & $\begin{array}{l}1.63 \\
.61\end{array}$ \\
\hline 6. & Physical load & $\begin{array}{l}1.63 \\
.67\end{array}$ & Unpleasant working conditions & $\begin{array}{l}1.73 \\
.71\end{array}$ \\
\hline 7. & Level of education & $\begin{array}{l}1.75 \\
.77\end{array}$ & Level of education & $\begin{array}{l}1.88 \\
.84\end{array}$ \\
\hline 8. & Language abilities & $\begin{array}{l}1.87 \\
.83\end{array}$ & Mental load & $\begin{array}{l}1.97 \\
.65\end{array}$ \\
\hline 9. & Company performance & $\begin{array}{l}2.02 \\
1.03\end{array}$ & Language abilities & $\begin{array}{l}2.00 \\
.69 \\
\end{array}$ \\
\hline 10. & Length of service & $\begin{array}{l}2.22 \\
1.03\end{array}$ & Length of service & $\begin{array}{l}2.07 \\
.85\end{array}$ \\
\hline 11. & Special personal character required for the job & $\begin{array}{l}2.27 \\
1.04\end{array}$ & $\begin{array}{l}\text { Special personal character required for } \\
\text { the job }\end{array}$ & $\begin{array}{l}2.25 \\
.77\end{array}$ \\
\hline 12. & Size of family the employee supports & $\begin{array}{l}2.61 \\
1.17\end{array}$ & Age & $\begin{array}{l}2.72 \\
.69\end{array}$ \\
\hline 13. & Age & $\begin{array}{l}3.29 \\
.95\end{array}$ & Size of family the employee supports & $\begin{array}{l}2.91 \\
.61\end{array}$ \\
\hline 14. & Gender & $\begin{array}{l}3.56 \\
.85\end{array}$ & Gender & $\begin{array}{l}3.00 \\
.44\end{array}$ \\
\hline
\end{tabular}

Note: a 4-point scale was used, where ' 1 ' means 'very important' and '4' 'not important'.

\section{Job satisfaction}

The results indicate that general satisfaction with work was higher among Finnish employees when gauged using the single question $(\mathrm{F}(1 ; 832)=24.253, \mathrm{p}=.000)$. The T-test revealed differences in 8 factors out of 15 , in which Finnish employees were more satisfied than their Estonian counterparts. The two countries are compared in Table 6 where statistically significant differences $(\mathrm{p}<.05)$ are highlighted in bold.

The Linear Regression analysis method reveals that the predictive value of the facets of the whole job satisfaction construct on general job satisfaction is similar in the two countries. The standardised Beta $(ß)$ coefficients which enable us to predict how the facets forecast general satisfaction, are presented in Table 6. In Estonia 44 percent of the variability in general satisfaction with work can be explained by reference to the 15 facets of job satisfaction presented in the current study: $\mathrm{R}^{2}=.441, \mathrm{~F}(15,514)=15.605, \mathrm{p}=.000$. In Finland 43 percent of the variability in general satisfaction can be explained by reference to the 15 facets of job satisfaction: $\mathrm{R}^{2}=.434, \mathrm{~F}(15,303)=$ $17.524, \mathrm{p}=.000$.
Results from the Linear Regression analysis indicate differences in the factors predicting general satisfaction with work life. The extent to which work is interesting and work load predict satisfaction with work in both countries. However, the remaining factors differ. Satisfaction with work in Finland depends also on satisfaction with pay and fringe benefits and relationships with the boss. In comparison in Estonia, instead of these factors, work conditions predict satisfaction with work (Table 6).

\section{Commitment to the company}

Although, according to the data in Table 6, commitment to the company was not statistically significantly different between Finnish and Estonian employees, there were differences in the factors influencing employees' commitment to the company. Feelings toward the company were taken as a dependent variable and employee job satisfaction was taken as an independent variable in the Linear Regression analysis. Table 6 presents the standardised coefficient Beta ( $(3)$. In Estonia 23 percent of variability in commitment to the company can be explained by reference to the 15 facets of job satisfaction presented in the current study: $\mathrm{R}^{2}=.225$, 
Table 6. Facets of job satisfaction affecting employee feelings toward the organization they work for and general satisfaction with work life

\begin{tabular}{|c|c|c|c|c|c|c|}
\hline & $\begin{array}{l}\text { Estonia } \\
\mathrm{N}=537 \\
\mathrm{M} \\
\mathrm{SD}\end{array}$ & $\begin{array}{l}\text { Finland } \\
\mathrm{N}=339 \\
\mathrm{M} \\
\mathrm{SD}\end{array}$ & $\begin{array}{l}\text { Feelings } \\
\text { toward } \\
\text { company } \\
\text { Estonia } \\
\text { Beta } \\
\mathrm{N}=531\end{array}$ & $\begin{array}{l}\text { Feelings } \\
\text { toward } \\
\text { company } \\
\text { Finland } \\
\text { Beta } \\
\mathrm{N}=323\end{array}$ & $\begin{array}{l}\text { General } \\
\text { satisfaction } \\
\text { Estonia } \\
\text { Beta } \\
\mathrm{N}=529\end{array}$ & $\begin{array}{l}\text { General } \\
\text { satisfaction } \\
\text { Finland } \\
\text { Beta } \\
\mathrm{N}=318\end{array}$ \\
\hline Working conditions & $\begin{array}{r}2.77 \\
.92\end{array}$ & $\begin{array}{r}2.30 \\
.93\end{array}$ & .005 & .064 & .115 & .026 \\
\hline $\begin{array}{lr}\text { Trust } & \text { between } \\
\text { managers } & \text { and } \\
\text { employees } & \\
\end{array}$ & $\begin{array}{r}2.81 \\
.93\end{array}$ & $\begin{array}{r}2.45 \\
.86\end{array}$ & -.173 & .009 & -.108 & -.012 \\
\hline Work load & $\begin{array}{l}2.89 \\
1.07\end{array}$ & $\begin{array}{r}2.37 \\
.87\end{array}$ & -.089 & .035 & .122 & .188 \\
\hline $\begin{array}{l}\text { Length of working } \\
\text { time }\end{array}$ & $\begin{array}{r}2.38 \\
.93 \\
\end{array}$ & $\begin{array}{r}2.05 \\
.79 \\
\end{array}$ & .034 & .042 & -.028 & .039 \\
\hline Pay and fringe benefits & $\begin{array}{l}3.80 \\
1.01\end{array}$ & $\begin{array}{l}3.01 \\
1.03\end{array}$ & .206 & .107 & .136 & .103 \\
\hline $\begin{array}{ll}\text { Competence } & \text { of } \\
\text { management }\end{array}$ & $\begin{array}{r}2.73 \\
.93 \\
\end{array}$ & $\begin{array}{r}2.54 \\
.79 \\
\end{array}$ & .263 & .119 & .091 & .018 \\
\hline $\begin{array}{l}\text { Promotion } \\
\text { opportunities }\end{array}$ & $\begin{array}{l}3.64 \\
1.10\end{array}$ & $\begin{array}{l}2.84 \\
1.02\end{array}$ & .192 & -.024 & .097 & .026 \\
\hline $\begin{array}{l}\text { Training and re- } \\
\text { training }\end{array}$ & $\begin{array}{l}3.19 \\
1.14\end{array}$ & $\begin{array}{l}2.69 \\
1.01\end{array}$ & -.049 & -.016 & .071 & .034 \\
\hline $\begin{array}{ll}\begin{array}{l}\text { Security } \\
\text { employment }\end{array} & \text { of } \\
\end{array}$ & $\begin{array}{l}3.36 \\
1.17\end{array}$ & $\begin{array}{l}2.24 \\
1.02\end{array}$ & -.074 & -.006 & .063 & .076 \\
\hline $\begin{array}{l}\text { Equal opportunities for } \\
\text { women and men }\end{array}$ & $\begin{array}{l}3.19 \\
1.04\end{array}$ & $\begin{array}{r}2.23 \\
.94 \\
\end{array}$ & -.067 & -.027 & .015 & .065 \\
\hline Welfare provision & $\begin{array}{l}3.94 \\
1.01 \\
\end{array}$ & $\begin{array}{r}2.53 \\
.92 \\
\end{array}$ & -.056 & .003 & .031 & -.054 \\
\hline $\begin{array}{l}\text { Relationship with your } \\
\text { boss }\end{array}$ & $\begin{array}{r}2.15 \\
.86 \\
\end{array}$ & $\begin{array}{r}1.93 \\
.87\end{array}$ & .159 & -.022 & .076 & .114 \\
\hline $\begin{array}{l}\text { Relationship with your } \\
\text { co-workers }\end{array}$ & $\begin{array}{r}1.79 \\
.68\end{array}$ & $\begin{array}{r}1.59 \\
.62\end{array}$ & -.067 & -.084 & -.125 & .081 \\
\hline $\begin{array}{l}\text { The extent to which } \\
\text { work is interesting }\end{array}$ & $\begin{array}{r}2.55 \\
.92\end{array}$ & $\begin{array}{r}2.06 \\
.85\end{array}$ & .237 & .252 & .359 & .356 \\
\hline $\begin{array}{lr}\text { Business } & \text { information } \\
\text { provided } & \text { by } \\
\text { management } & \\
\end{array}$ & $\begin{array}{l}1.53 \\
1.10\end{array}$ & $\begin{array}{l}2.90 \\
1.03\end{array}$ & .049 & -.023 & .084 & -.009 \\
\hline General satisfaction & $\begin{array}{r}2.91 \\
.98\end{array}$ & $\begin{array}{r}2.12 \\
.73\end{array}$ & & & & \\
\hline $\begin{array}{l}\text { Feelings towards the } \\
\text { company }\end{array}$ & $\begin{array}{r}1.95 \\
.69 \\
\end{array}$ & $\begin{array}{r}1.29 \\
.52 \\
\end{array}$ & & & & \\
\hline
\end{tabular}

General satisfaction was evaluated on a 5-point scale, where ' 1 ' signifies 'very satisfied' and '5'very dissatisfied'.

'Feelings towards the company" were evaluated on a 4-point scale, where:

1 - 'I would like to put my best effort towards the company's success';

2 - 'I would like to give as much effort to the company as the company gives to me as reward';

3 - 'I do not have much feeling towards the company';

4 - I am indifferent to any matters concerning the company'.

Bold notes statistically significant relationships, $\mathrm{p}<.05$.

$\mathrm{F}(15,516)=6.272, \mathrm{p}=.000$. In Finland this figure is smaller: only 7 percent of variability can be explained by reference to the same facets of job satisfaction: $\mathrm{R}^{2}=$ $.070, \mathrm{~F}(15,289)=2.510, \mathrm{p}=.002$.

The results in Table 6 indicate that in Estonia pay and fringe benefits, competence of management, relationships with managers, promotion opportunities and the extent to which work is interesting predict commitment to the company. However, in Finland only the extent to which work is found to be interesting predicts commitment to the company.

\section{Discussion and conclusions}

Despite the geographical proximity and relatively close cultural ties between Estonia and Finland the survey revealed significant differences in attitudes toward work, organisation and society in these countries. 
On the societal level respondents from Estonia put more emphasis on their material standard of living. The reason may stem from difficulties in satisfying lower level needs. According to Maslow's (1954) hierarchy of needs Estonians may start to value cooperation only after satisfying these lower level needs.

The same phenomenon could be seen in the ranking of pay determinants. Estonian respondents gave the highest ranking to unpleasant working conditions. Finnish respondents on the other hand were interested in connecting their salaries to company performance, which was not an issue in Estonia.

There were significant differences between the two countries concerning trade unions. Although TU membership was higher in Finland, TU members in Finland tend to be "card carriers". This means they are willing members of the union but do not participate uniformly (Nicholson et al., 1981). The high TU membership in Finland may be due to various reasons. On the one hand, research indicated that respondents from Finland found that decisions made by local unions tended to represent their opinions while respondents from Estonia thought otherwise. On the other hand, being a TU member may also be tradition. In Estonia the past has exerted a significant influence because within the Soviet system trade unions were affiliated with the communist party (Nurmi and Üksvärav, 1994:66) and did not represent employees' interests in the traditional way. The trust, which was lost when trade unions stopped fulfilling their traditional roles, is still a long way from being restored.

TUs were, to a large extent, formal organisations to which everyone in the Estonian workforce had to belong. After Estonia regained its independence, the TU system was dismantled and as current research indicates, people still do not find TUs useful. There were different expectations concerning the spheres of TU activities: respondents from Finland, for example, put more emphasis on increasing influence over management policies than Estonian respondents.

In Finland job satisfaction was higher than in Estonia. Although commitment to the company was not statistically significantly different between Finnish and Estonian employees, there were differences in the factors influencing employees' commitment to the company. In Estonia pay and fringe benefits, competence of management, relationships with managers, promotion opportunities and the extent to which work is interesting predict commitment to the company. In Finland, however, only the extent to which work is found to be interesting predicts commitment to the company. It seems that in Finland companies are quite similar in terms of quality of management, type of job and promotion opportunities. In Estonia, in comparison, these factors vary more and according to subordinates' views managers still lack competence. This finding supports the view that the syndrome of 'management Sovieticus' (Liuhto, 1999:137, Nurmi and Üksvärav, 1994) has damaged Estonian management culture more than it is possible to heal in only ten years.

In attempting to explain these results, the last 50 years under principally different regimes could be taken into consideration. In 1940 the two countries were separated by the 'Iron Curtain'. These 50 years, during which time the Estonian economy was almost destroyed and the communist party tried to change the way people think, have impacted on this difference in attitudes. Four sets of explanations are considered.

First, the reasons for the differences in these attitudes may stem from the different developmental stages of the respective market economies. Finland underwent comparatively stable, capitalist economic growth, whereas Estonia was subjected to 50 years of the Soviet system and major system upheavals in 1940 and 1991.

Second, many of these differences may stem from the existence of different ideologies. In totalitarian societies people's choices are constrained because of the use of coercive forms of political and economic control (Eagly and Chaiken, 1993). In contrast, Finland with a democratic political system, presented people with many choices. This difference at the societal level is also carried through to organisations. Üksvärav $(2001: 106,118)$ found that well developed hierarchies, where people expect answers to problems to be decided by someone higher up and even managers were inclined to rely on help and direction from higher authority, was one of the outstanding features of the Soviet era in Estonia. Although Finnish organisations tended to be more hierarchical than organisations in other Scandinavian or Anglo-Saxon countries, Finnish managers neither needed nor asked the opinion of many people before making decisions (Nurmi and Üksvärav, 1994:60). Finns enjoy work when authority and responsibility are defined by means of an appropriate goal setting procedure and they are left to get on with their work (ibid: 65). Therefore, when the post-Soviet transition of Estonian society started, employees had a certain legacy of working habits and attitudes toward organisational tasks. However, these are somewhat different to what is needed by organisations in a market economy. 
Third, the time that Estonia has had to move from a totalitarian regime to a democratic system has been too short to develop a sufficient level of welfare as the basis for employee self-reliance. As support for the unemployed is not sufficient, employees are afraid of losing their jobs and this fear influences their attitudes.

Fourth, these differences can be explained from an institutional perspective. In a transition economy with new and as yet unstable institutions, survival needs dominate the formation of people's attitudes. In contrast, in an established capitalist country such as Finland, with stable institutions, the problem of survival has already been resolved and higher level needs dominate. This difference in the level of needs satisfaction influences employees' attitudes and expectations toward society and trade unions.

One conclusion from this study is that the significant differences in attitudes held toward society, organisations and work by people in Estonia and Finland are influenced by different levels of institutional development. Despite their common historical roots, 50 years under widely different economic and ideological systems have influenced both material resources and human beings. The experiment with communism in Estonia distorted normal economic development and caused difficulties in need satisfaction. These factors have in their turn influenced attitudes and expectations toward society, trade unions and work organisations. It seems that Estonia still has much to do before higher order needs can take over as motivating forces. However, in order to draw broader conclusions it is necessary to explore alternative explanations and conduct further empirical research in other industries.

\section{References}

Alas, R. (2003) Employee's attitudes in countries with different past, Journal of Business Economics and Management, 3(1), 45-52.

Alas, R., \& Vadi, M. (2003) The Impact of Organisational Culture on Organisational Learning in Six Estonian Hospitals, Trames, 7(2), 83-98.

Alas, R., \& Vadi, M. (2004) The Impact of Organisational Culture on Attitudes Concerning Change in Post-Soviet Organisations', Journal for East European Management Studies, 9(1), 20-39.

Bamberger, P. A., Kluger, A. N., \& Suchard, R. (1999) The Antecedents and consequences of Union Commitment: a Meta-analysis, Academy of Management Journal, 42(3), 304-318.

Bean, R., \& Holden, K. (1994) Determinants of Trade Union Membership in OECD Countries: A Survey,
International Journal of Manpower, 15(6), 4-37.

Boninger, D. S., Krosnick, J. W., \& Berent, M. K. (1995) Origins of Attitude Importance: Self-interest, Social Identification, and Value Relevance, Journal of Personality and Social Psychology, 68, 61-80.

Bergquist, W. (1993) The Postmodern Organisation: Mastering the Art of Irreversible Change, San Francisco: Jossey-Bass Publishers.

Brief, A. P. (1998) Attitudes In and Around Organisations, London: Sage Publications.

Clark, E., \& Soulsby, A. (1999) Organizational Change in Post-Communist Europe: Management and transformation in the Czech Republic, London: Routledge.

Cooper, J., \& Croyle, R. T. (1984) Attitude and Attitude Change, Annual Review of Psychology, 35, 394-426.

Eagly, A. H., \& Chaiken, S. (1993) The Psychology of Attitudes, TX: Harcourt College Publishers.

Fairbrother, P. (2000) British Trade Unions Facing the Future, Capital \& Class, 72, 47-79.

Freeman, R. B. (1994) Working under Different Rules, New York: Russell Sage.

Hickson, D. \& Pugh, D. (2001) Management Worldwide, London: Penguin, $2^{\text {nd }}$ ed.

Hinnosaar, M. (2003) Eesti tööturu institutsionaalne raamistik rahvusvahelises võrdluses, Eesti Panga Toimetised, 7.

Hurst, D. K. (1995) Crisis and Renewal: Meeting the Challenge of Organisational Change, Boston: Harvard Business School Press.

Johnson, W. R., \& Jones-Johnson, G. (1992) Differential Predictors of Union and Company Commitment: Parallel and Divergent Models, Psychology, 29, 1-12.

Judge, T. A., Parker, S. H., Colbert, A. E., Heller, D., \& Ilies, R. (2001) 'Job Satisfaction: A Cross-Cultural Review', In: Anderson, N., Ones, D. S., Sinangil, H. K., and Viswesvaran, C. (Eds.), Handbook of Industrial, Work \& Organisational Psychology, 2, 25-52. Organisational Psychology, London: Sage Publications.

Kallaste, E., \& Philips, K. (2003) 'Tööjõu vaba liikumine - probleem või võimalus Eestile?', Riigikogu Toimetised 7, 119-128.

Laar, M. (2001) Back to the Future, Proceedings of the Center Right Conference '10 years of Freedom in Central Europe', Estonia.

Liuhto, K. (1999) The Organisational and Managerial Transformation in Turbulent Business Environments Managers' views on the transition of their enterprise in some of the European former Soviet republics in the 1990 's. Publications of the Turku School of Economics and Business Administration, Series A-9.

Locke, E. A. (1976) The nature and causes of job satisfaction, in Dunnette, M. D. (Ed.) Handbook of Industrial and Organisational Psychology (pp. 1297- 
1343). Chicago: Rand McNally.

Maslow, A. H. (1954) Motivation and personality, New York: Harper and Row.

McNeese-Smith, D. K., \& Nazarey, M. (2001) A Nursing Shortage: Building Organizational Commitment among Nurses / Practicioner Application, Journal of Healthcare Management, 46(3), 173-187.

Meyer, J. P., \& Allen, N. J. (1997) Commitment in the Workplace: Theory, Research and Applications, London: Sage Publications.

Meyer, J., Boli, J., \& Thomas, G. (1994) 'Ontology and rationalization in the Western Cultural Account', in Scott, W. R. et al (eds.) Institutional Environments and Organizations: Structural Complexity and Individualism, London: Sage, pp. 9-27.

Misiunas, R. J., \& Taagepera, R. (1983) The Baltic States: Years of Dependence, 1940-1980. London: Hurst; and Berkeley: University of California Press.

Muller-Jentsch, W. (1985) Trade Unions as International Organizations, Economic and Industrial Democracy, 6(1), 3-33.

Narusk, A. (2004) Välismaa peibutab eestlasi ajutise tööga, Päevaleht, 22 March.

Nicholson, N., Blyton, P., \& Ursell, G. (1981) The Dynamics of White Collar Trade Unionism, London: Academic Press.

Nurmi, R., \& Üksvärav, R. (1994) 'Estonia and Finland: Culture and Management, a Conceptual Presentation', Publications of the Turku School of Economics and Business Administration. Series A-9.

O’Reilly, C. A., \& Chatman, J. (1986) 'Organisational commitment and psychological attachment: The effects of compliance, identification, and internalization on prosocial behavior', Journal of Applied Psychology, 71, 492-499.

Raun, T. (1987) Finland and Estonia: Cultural and Political Relations, Journal of Baltic Studies, 18(1), 5-20.

Sahlins, M. (1985) Islands of History, Chicago: University of Chicago Press.

Schneider, S. and Barsoux, J.-L (1997) Managing Across Cultures, London: Prentice Hall.

Spector, P. E. (1997) Job Satisfaction: Application, Assessment, Causes, and Consequences, London: Sage Publications.

Taagepera, R. (1987) 'Who Assimilates Whom? - The World and the Baltic Region', Journal of Baltic Studies, 18(3), 269-282.

Tayeb, M. (1991) 'Socio-political environment and management-employee relationships, An empirical study of England and India', in Brewster, C. and Tyson, S. (eds) International Comparisons in Human Resource Management, London: Pitman, pp. 44-63.

'The Free Movement of Workers in the Context of Enlargement' (2001) European Commission Information Note.

Üksvärav, R. (2001) 'Management Culture in Estonia: Past and Present Features', in Suominen, A. (Ed.) Searching for the Boundaries of Business Culture, Publications of the Turku School of Economics and Business Administration Series C-1, pp. 103-120.

Wood, G., \& Brewster, C. (2002) 'Decline and Renewal in the British Labour Movement: Trend, Practices and Lessons for South Africa', Society in Transition, 33(2), 241-257. 